УДК 378.091.12.011.3-051; 373.2

DOI:

Людмила Машкіна, кандидат педагогічних наук, доичент кафедри дошкільної педагогіки, психології та фахових методик, Хмельницької гуманітарно-педагогічної академії

\title{
ФОРМУВАННЯ ФАХОВОЇ КОМПЕТЕНТНОСТІ МАЙБУТНІХ ВИХОВАТЕЛІВ ДІТЕЙ ДОШКІЛЬНОГО ВІКУ В ОСВІТНЬОМУ ПРОЦЕСІ ЗАКЛАДІВ ВИЩОЇ ОСВІТИ
}

У статті розкрито сутність поняття “фахова компетентність вихователя дітей дошкільного віку”, обтрунтовано ї̈ основні компоненти та описані етапи формування цієї компетентності. Звернено увагу на розвивальну, комунікативну, діагностичну, прогностичну та інші види компетенцій. Акцентовано на основних компонентах фахової компетентності як-от мотиваційний, змістовний, особистісний, рефлексивний та ін. Описано етапи становлення фахової компетентності майбутніх вихователів під час освітнього процесу.

Ключові слова: компетентність; освітній прочес; заклади вищої освіти; вихователь дітей дошкільного віку. Jim. 7.

Lyudmyla Mashkina, Ph.D.(Pedagogy), Associate Professor of the Preschool Pedagogy, Psychology and Professional Methods Department Khmelnytskiy Humanitarian Pedagogical Academy

\section{FORMATION OF PROFESSIONAL COMPETENCE OF FUTURE EDUCATORS OF PRESCHOOL CHILDREN IN THE EDUCATIONAL PROCESS OF HIGHER EDUCATION INSTITUTIONS}

The article reveals the essence of the concept "professional competence of future educators of preschool children" substantiates its main components and describes the stages of formation of this competence. It is revealed that competence is a characteristic that a person receives during the process of evaluating the effective implementation of actions aimed at solving problems.

The concept "professional competence" as a structural element of the concept of "competence" is considered, which means the ability of a specialist to make decisions in the process of his own professional activity. As a result of the investigated problem, it was determined that the competence of future educators of preschool children characterizes the ability to perform professional activities on the basis of the acquired knowledge, skills and abilities at a higher educational institution.

The attention is paid to developing, communicative, diagnostic, predictive, self-improving and other types of competences as the main components of professional competence. The main components of professional competence are emphasized, such as motivational, informative, personal, reflexive and operational-activity, which are interrelated and interdependent and the importance of each component for the acquisition of professional competence from future specialists in the pre-school sector.

The basic skills of future educators of preschool children as the basis of professional competence are determined, among them creation of atmosphere of personal communication in the institution of preschool education, providing of activity of the child, etc. The importance of a full-fledged educational process in the institution of higher education for successful formation of professional competence among of future educators of preschool children has been investigated.

Keywords: competence; an educational process; institutions of higher education; a teacher of pre-school children.

П остановка проблеми в загальному вигляді. Новий напрямок розвитку України, інтеграція у європейську спільноту, реформування багатьох сфер життя, зумовило зміни у сфері освіти. У зв'язку з цим важливого значення набуває підготовка фахівців освітнього профілю: вихователів, вчителів, викладачів. Так, відповідно до нормативноправових документів, таких як Державна національна програма “Освіта" (Україна XXI століття), Національна доктрина розвитку освіти, Закон України "Про освіту”, "Про вищу освіту" освіта України має відповідати рівню освіти розвинутих держав. В українському законодавстві зазначено, що первинною ланкою системи освіти $€$ дошкільна, яка має значний вплив на формування людини як особистості та $\epsilon$ фундаментом, який забезпечує всебічний гармонійний розвиток особистості [6].

Для досягнення поставленої мети важливим $\epsilon$ підготовка нових педагогічних кадрів, в тому числі і вихователів дітей дошкільного віку, які повинні мати високий загальнокультурний та професійний рівень розвитку, а також бути 


\section{ФОРМУВАННЯФАХОВОЇ КОМПЕТЕНТНОСТІМАЙБУТНІХ ВИХОВАТЕЛІВ ДІТЕЙ ДОШКІЛЬНОГО ВІКУ В ОСВІТНЬОМУ ПРОЦЕСІ ЗАКЛАДІВ ВИЩОЇ ОСВІТИ}

конкурентоспроможними фахівцями у сфері освіти. У зв'язку з цим вищі навчальні заклади мають забезпечувати якісну підготовку педагогів 3 високим рівнем сформованої фахової компетентності [4].

Аналіз останніх досліджень і публікацій. Аналіз наукових джерел засвідчив, що в психолого-педагогічній науці приділяється значна увага професійній підготовці, зокрема таким іiі аспектам, як: філософія освіти (В. Андрущенко, В. Кремень, В. Огнев'юк); психологічні основи професійного становлення педагога (О. Божович, О. Леонтьєв, О. Пєхота, С. Рубінштейн); формування педагогічної майстерності (І. Зязюн, Л. Кондрашова, В. Семиченко); професійна компетентність педагогів (Н. Бібік, Н. Глузман, I. Зимняя, О. Овчарук, О. Олексюк, О. Пометун, С. Сисоєва, Л. Хоружа, А. Хуторський). Проблеми формування фахової компетентності розкрито у дослідженнях Н. Кузьміної, Н. Ничкало, О. Савченко, О. Шиян та ін., щодо вихователів дітей дошкільного віку, то науковці здебільшого характеризують поняття "професійна компетентність" та обгрунтовують деякі аспекти фахової компетентності (Г. Бєлєнька, А. Богуш, Н. Денисенко, Е. Карпова, О. Кононко, Н. Лисенко, Т. Поніманська та ін.).

Мета статті - розкрити сутність поняття “фахова компетентність вихователя дітей дошкільного віку” та обгрунтувати етапи іiі набуття.

Виклад основного матеріалу. Становлення дошкільної освіти потребує підготовки вихователя дітей дошкільного віку нової формації, адже здійснюється перебудова взаємодії педагога 3 дитиною, оновлюється зміст освіти тощо, тому і висуваються вимоги до фахової компетентності вихователів. У сфері освіти результат підготовки вихователів дітей дошкільного віку розглядається у понятті “компетенція" та “фахова компетентність". Вважаємо за необхідне охарактеризувати дані поняття. Компетенцією називають в першу чергу зазначену вимогу до освітньої підготовки фахівця певної галузі, характеристика діяльності особистості (Г. Бєлєнька, І. Зимня, Н. Кузьміна, К. Шапошніков та ін.) [3].

Розглядаючи “компетентність” як характеристику особистості відзначимо, що дане поняття є ширшим за поняття “знання”, “вміння”, “навички” адже воно поєднує їх у собі. Компетентність $є$ характеристикою, яку отримує людина в процесі оцінки результативного виконання певних дій, які спрямовуються на вирішення проблем [3].

У світлі оновленого Закону України “Про освіту" від 05.09.2017 відзначимо, що компетентність $є$ динамічною комбінацією знань, умінь, що визначає здатність особи успішно соціалізуватися, проводити професійну та/або подальшу навчальну діяльність [6].

Аналізуючи визначення досліджуваного поняття науковці виокремлюють компетентність як інтегративне утворення особистості, яке включає знання, уміння, навички, досвід та особистісні властивості, що допомагають розв'язувати поставленні проблеми та завдання, які виникають в житті та у професійні сфері [3].

Фахова компетентність $є$ структурною одиницею поняття “компетентність”. Вона передбачає володіння вихователями дітей дошкільного віку професійною діяльністю на високому рівні, яка й формуватиме конкурентоспроможність фахівця.

Загалом поняття “фахова компетентність” як складний феномен вивчають I. Зязюн, Н. Кузьміна, Н. Ничкало, О. Савченко, О. Шиян та ін. Поняття "фахова компетенція" вони досліджують у двох напрямках: широкому та вузькому. Щодо вузького сенсу, то це є готовність та здатність фахівця приймати ефективні рішення під час професійної діяльності. У широкому значенні фаховою компетенцією $є$ сукупність інтегрованих знань, умінь та досвіду, а також якостей особистості, які дозволяють людині здійснювати професійну діяльність під час взаємодії з оточуючим світом [7].

Проблема формування фахової компетентності вихователів дітей дошкільного віку вивчається у дослідженнях сучасних науковців, зокрема, Л. Артемової, Г. Бєлєнької, Ю. Косенко та ін. Фахова компетентність, на їх думку, складаються 3 діяльнісного та когнітивного компонента, іiї рівень $є$ головним критерієм аналізу відповідності фахівця вимогам майбутньої діяльності. Основними елементами даної компетентності на думку Л. Артемової та Ю. Косенко є система фахових знань, що включають психологічні, загальнодидактичні та спеціальні; система фахових умінь а також професійні здібності та риси особистості педагога. Для успішного набуття фахової компетентності необхідно сформувати у майбутніх вихователів світогляд та професійну спрямованість, щоб студенти засвоювали знання та уміння; змогли розвивати професійні здібності вже із студентських років [1].

Фахова компетентність вихователя дітей дошкільного віку є характеристикою здатності майбутнього вихователя виконувати професійну діяльність на основі здобутих у вищому навчальному закладі знань, умінь та навичок, 


\section{ФОРМУВАННЯФАХОВОЇ КОМПЕТЕНТНОСТІМАЙБУТНІХ ВИХОВАТЕЛІВ ДІТЕЙ ДОШКІЛЬНОГО ВІКУ В ОСВІТНЬОМУ ПРОЦЕСІ ЗАКЛАДІВ ВИЩОЇ ОСВІТИ}

найголовнішими серед яких є любов до дітей, що поєднується як вимогливістю, емпатія та комунікативність. Загалом компетенції, якими повинен володіти кваліфікований вихователь включають навчально-розвивальну, виховну, комунікативну, просвітницьку, плануючу, контролюючу, самовдосконалюючу, діагностичну та прогностичну, а також організаційнопедагогічну [1].

Розкриємо детальніше компетенції, які $є$ складовими фахової компетентності. Діагностична компетенція полягає у вмінні вихователя вивчати здібності дітей, особливості їх всебічного розвитку, рівні та умови виховання тощо. Прогностична - це здатність педагога визначати напрямок своєї діяльності після проведеної діагностики. Плануюча - означає використання різноманітних форм роботи з дітьми дошкільного віку для досягнення певного результату на основі визначеного напрямку власної діяльності. Організаційно-педагогічна компетенція - це вміння фахівця залучати дітей до певних видів діяльності, вміння співпрацювати та взаємодіяти 3 ними для досягнення поставленої мети. Комунікативна компетенція є надзвичайно важливою для педагога. Вона полягає у вмінні вибудовувати ефективний комунікативний процес 3 дітьми, батьками та колегами; знання та правильне застосування різних форм та стилів спілкування, в залежності від того, з ким він спілкується та яка виникла ситуація. Самовдосконалююча - це вміння вихователя займатися саморозвитком, прагнути здійснювати творчий підхід до власної професійної діяльності, щоб досягнути максимальної ефективності під час роботи 3 дітьми дошкільного віку. Навчальнорозвивальна компетенція тісно переплітається 3 виховною, адже навчання без виховання не можливе, так як і виховання без навчання. Вони полягають в оволодінні знаннями, вміннями та навичками, що дають змогу успішно здійснювати професійну педагогічну діяльність, досягати поставленої мети щодо навчання, виховання дітей дошкільного віку, яка полягає у всебічному та гармонійному розвитку особистості. Просвітницька - це вміння вихователя повідомляти ті знання та інформацію, якої потребують дошкільники, їх батьки тощо. Контролююча компетенція складається з умінь педагога аналізувати, вивчати виконану роботу з дітьми; здійснювати контроль щодо виконання поставних педагогом вимог тощо [2].

Оволодіваючи даними компетенціями, педагог-фахівець дошкільного профілю зможе успішно виконувати дві важливих ролі у роботі 3 дітьми: вчитиме дітей, допомагати їм набувати нових знань та виховуватиме; здійснюватиме зацікавлення, захоплення, творчо мотивуватиме. Завдяки цьому вихователь формуватиме у дошкільників вміння сприймати події суспільства та явища навколишнього середовища, проявляючи різні почуття: емоції, переживання тощо.

Досліджуючи фахову компетентність науковці обгрунтовують їі основні компоненти [7]. Вважаємо за необхідне розкрити їх детальніше:

- мотиваційний компонент включає позитивну мотивацію до майбутньої професійної діяльності, бажання працювати в обгрунтованій галузі;

- змістовний компонент включає систему професійних знань, володіння якими сприяє успішній професійній діяльності;

- операційно-діяльнісний компонент складається 3 умінь вирішувати різні педагогічні завдання та проблеми, володіння фаховим мисленням та інноваційними педагогічними технологіями, необхідними для успішної роботи з дітьми дошкільного віку;

- особистісний компонент охоплює особистісні та професійні якості особистості, зокрема емпатійність, креативність, ініціативність, гнучкість, адаптивність, любов до дітей тощо;

- рефлексивний є останнім компонентом фахової компетентності, який дозволяє здійснювати педагогові рефлексію, а також здійснювати процеси самопізнання, саморозвитку, самовдосконалення.

Фахова компетентність майбутнього вихователя дітей дошкільного віку повинна включати такі вміння, як створення атмосфери особистісного спілкування в закладі дошкільної освіти; забезпечення активності дитини в різних напрямках, наприклад: фізична активність, пізнавальна і мовленнєва і т. д.; вміння застосовувати моделі тих видів діяльності, яких дошкільник потребує, в тому числі і спілкування, гра, навчальна діяльність тощо.

Підготовка майбутніх вихователів дітей дошкільного віку, формування їх фахової компетентності здійснюється під час освітнього процесу, який включає безпосередньо навчальну діяльність, практичну, тобто проходження різних видів педагогічної практики та інші джерела здобуття професійних знань, умінь та навичок, зокрема, відвідування конференцій, тренінгів, семінарів, читання додаткової літератури тощо. Тому освітній процес, на нашу думку є важливим аспектом у формуванні фахової компетентності, адже завдяки професіоналізму викладачів закладу вищої школи, майбутні фахівці дошкільної освіти 


\section{ФОРМУВАННЯФАХОВОЇ КОМПЕТЕНТНОСТІ МАЙБУТНІХ ВИХОВАТЕЛІВ ДІТЕЙ ДОШКІЛЬНОГО ВІКУ В ОСВІТНЬОМУ ПРОЦЕСІ ЗАКЛАДІВ ВИЩОЇ ОСВІТИ}

отримують саме ті знання, які знадобляться їм на професійному шляху.

Ефективність успішного формування фахової компетентності майбутніх вихователів дітей дошкільного віку під час освітнього процесу залежить від правильно підібраного та чіткого змісту освітньої діяльності, а також використання ефективних методів і прийомів навчання. Високий рівень даної компетентності характеризуватиметься ступенем позитивної реакції, впливу студентів на довколишню дійсність та безпосередньо на освітній процес у закладі дошкільної освіти з їх учасниками. Також важливим $\epsilon$ те, що наявність високого рівня фахової компетентності педагога допомагає здійснювати вплив на довколишню дійсність через взаємодію та співпрацю 3 вихованцями, їхніми батьками та усіма оточуючими, що пов'язується із збільшенням професійних знань, умінь, навичок, розширенням досвіду, напрямками і сферами професійної діяльності [1].

Освітній процес складається 3 ряду професійно-орієнтованих дисциплін, які узгоджуються між собою для досягнення головної цілі: формування особистості педагога, конкурентоспроможного та компетентного фахівця в галузі дошкільної освіти.

Досліджуючи освітній процес у підготовці вихователів, відзначимо, що процес становлення фахової компетентності складається 3 декількох етапів.

Першим етапом $\epsilon$ перші роки навчання, коли студент отримує основи фахової компетентності, які складаються 3 певних інформаційних компонентів, мотиваційних і базових, зокрема 3 фахових дисциплін “Вступ до спеціальності”, “Дошкільна педагогіка" та ін.

На другому етапі процес формування фахової компетентності здійснюється завдяки розвитку загальнокультурної, психолого-педагогічної, креативної, комунікативної компетенцій. Важливими на даному етапі оволодіння знаннями 3 фахових дисциплін, серед яких педагогіка, психологія та фахові методики, при засвоєнні яких майбутні вихователі здобувають інформацію про розвиток дітей дошкільного віку, особливості роботи з ними в рамках отримання дітьми дошкільної освіти.

Процес формування фахової компетенції продовжується на даному етапі і під час проходження різних видів педагогічної практики, під час якої студенти оволодівають сучасними методами та формами освітньої роботи в закладах дошкільної освіти, удосконалюють свої професійні уміння та навички, а також здійснюють

практичне закріплення здобутих теоретичних знань у роботі з дітьми дошкільного віку. Саме педагогічна практика доповнює теоретичну підготовку студентів, отриману під час освітнього процесу у вищому навчальному закладі. Саме під час даного виду роботи більшість студентів визначають правильність обраної сфери діяльності, з'ясовують співвідношення особистісних якостей $з$ власне професійною діяльністю [2].

На третьому етапі (це здобуття вищої освіти - рівень бакалавра та магістра) реалізуються професійні потреби, систематизуються та поглиблюються знання вихователя дітей дошкільного віку, завершується формування фахової компетентності фахівця, який включає високий рівень базових та спеціальних компетенцій для успішної професійної діяльності.

Оскільки гаслом сучасності є “навчання протягом життя”, на нашу думку варто виділити і четвертий етап формування компетенцій педагогів дошкільного профілю, який полягає у післядипломному навчанні, що реалізується у формі курсів підвищення кваліфікації, перепідготовки, проходження атестації, сертифікації тощо.

На думку Г. Бєлєнької, до цих етапів варто віднести адаптаційно-орієнтувальний, коли студент усвідомлює та осмислює вибір своєї професії, здійснюється корекція ціннісних життєвих пріоритетів, оволодіває спеціальними уміннями навчатися та формуються основні позиції та принципи життя; змістово-рефлексійний - відбувається процес набуття знань та професійних умінь, осмислюється їх значення, розкриваються індивідуальні особливості та формуються професійні здібності; практикоперетворювальний етап полягає в інтеграції роботи в педагогічному середовищі та творчої самореалізації в процесі роботи 3 дітьми дошкільного віку, тобто вихователь дітей дошкільного віку отримує можливість самореалізуватися у своїй професійній діяльності [1].

Висновки. Таким чином, ефективне та якісне формування фахової компетентності у майбутніх вихователів дітей дошкільного віку залежить від розвитку багатьох компетенцій: навчальнорозвивальної, виховної, комунікативної, просвітницької, плануючої, контролюючої, самовдосконалюючої, діагностичної та прогностичної, а також організаційно-педагогічної. Аналіз досліджень 3 даної проблеми показав, що головним аспектом формування фахової компетенції у майбутніх вихователів дітей 


\section{ФОРМУВАННЯФАХОВОӤ КОМПЕТЕНТНОСТІМАЙБУТНІХ ВИХОВАТЕЛІВ ДІТЕЙ ДОШКІЛЬНОГО ВІКУ В ОСВІТНЬОМУ ПРОЦЕСІ ЗАКЛАДІВ ВИЩОЇ ОСВІТИ}

дошкільного вікує повноцінний освітній процес, який не закінчується при здобутті певного освітнього ступеня у закладі вищої освіти, а продовжується протягом усієї професійної діяльності.

Перспективи подальших розвідок Проведене дослідження не є вичерпним щодо даної проблеми. Перспективним, на нашу думку $\epsilon$ вивчення та обгрунтування особливостей кожного етапу формування фахової компетентності у майбутніх вихователів дітей дошкільного вікута визначення педагогічних умов їх реалізації.

\section{ЛІТЕРАТУРА}

1. Бєлєнька Г. В. Формування професійної компетентності майбутніх вихователів дітей дошкільного віку в умовах університетської освіти / Г. В. Бєлєнька // Психолого-педагогічні науки. 2012. - № 4. - C. 17 - 22.

2. Головань М. С. Компетенція і компетентність досвід теорії, теорія досвіду / М.С. Головань // Вища освіта України. - 2008. - № 3. - С. 23-30.

3. Гуцан Л. А. Компетентнісний підхід в освіті. Проблеми, поняття, інструментарій / Л. А. Гуцан // Зарубіжна література. - 2006. - № 27. - С. 16 28.

4. Національна доктрина розвитку освіти: затв. Указом Президента України від 17.04.2002 р. № 347/2002. [Електронний ресурс]. - Режим доступу: http://zakon.rada.gov.ua /laws/show/ 347/ $\underline{2002}$

5. Про вищу освіту: Закон України від 01.07.2014 p. № 1556-VII. Дата оновлення: 22.05.2018. [Електронний ресурс]. - Режим доступу: http://zakon.rada.gov.ua/ laws/show/1556$\underline{18}$

6. Про освіту: Закон України: від 05.09.2017 р. № 2145-VIII. [Електронний ресурс]. - Режим доступу: http://zakon.rada.gov.ua/laws/show/2145-19

7. Чаговець А. Сучасна професійна підготовка майбутніх вихователів дошкільних навчальних закладів. Теоретичний аспект / А. Чаговець // Обрії. - 2015. - № 1. - С. 99 - 102.

\section{REFERENCES}

1. Byelyenka, G. V.(2012). Formuvannya profesijnoyi kompetentnosti majbutnix vyxovateliv ditej doshkilnogo viku $\mathrm{v}$ umovax universytetskoyi osvity [Formation of professional competence of future educators of preschool children in the conditions of university education]. Psycholological and pedagogical sciences. No. 4, pp. 17-22. [in Ukrainian].

2. Golovan, M. S. (2008). Kompetenciya i kompetentnist: dosvid teoriyi, teoriya dosvidu [Competence and competence: experience of theory, theory of experience]. Higher education of Ukraine, No. 3, pp. 23-30. [in Ukrainian].

3. Guczan, L. A. (2006). Kompetentnisnyj pidxid v osviti. Problemy, ponyattya, instrumentarij [Competency approach in education. Problems, concepts, tools]. Word Literatyre, No. 27, pp. 1628. [in Ukrainian].

4. Nacionalna doktryna rozvytku osvity [National Doctrine of Education Development]. [Electronic resource]. Available at: http://zakon.rada.gov.ua / laws/show/347/2002 [in Ukrainian].

5. Pro vyshhu osvitu: Zakon Ukrayiny [About Higher Education: The Law of Ukraine]. [Electronic resource]. Available at: http://zakon.rada.gov.ua/ laws/show/1556-18 [in Ukrainian].

6. Pro osvitu: Zakon Ukrayiny [About Education: The Law of Ukraine]. [Electronic resource]. Available at: http://zakon.rada.gov.ua/laws/show/ 2145-19 [in Ukrainian].

7. Chagovecz, A. (2015). Suchasna profesijna pidgotovka majbutnix vyxovateliv doshkilnyx navchalnyx zakladiv. Teoretychnyj aspekt [Contemporary professional training of future educators of pre-school educational institutions. Theoretical aspect]. Horizons, No. 1. pp. 99-102. [in Ukrainian].

Стаття надійшла до редакції 05.12.2018

\section{G580}

"Адже залишити себе в наших вихованиях мій друже, ие не означає механічно переқласти знання із своєї голови в голови тих, кого ми навчаємо. Не можна ні на мить забувати того, що, допомагаючи людині пізнавати навколишній світ, ми самі постаємо перед ї̈ розумом $і$ серием як найважливіший елемент навқолишнього світу. Тізнаючи світ, людина не може не пізнавати і нас. Знання, що ми ій даємо, не єчимось невіддільним від нашої особистості. Вони злиті із світом людсьқих почуттів $i$ переживань”.

Василь Сухомлинський “Сто порад учителеві” педагог, публіиист, письменник

\section{G58080}

Молодь і ринок №1 (168), 2019 